\title{
The Impact of Halfway Houses on Parole Success and Recidivism
}

\author{
S.E. Costanza (Corresponding author) \\ Center for Public Policy \\ University of South Alabama, United States \\ Email: scostanza@southalabama.edu \\ Stephen M. Cox \\ Central Connecticut State University \\ Department of Criminology \& Criminal Justice, United States \\ Email: coxs@ccsu.edu
}

$\mathrm{Ph} \#$ (860) 832-3138, Fax (860) 832-3014

John C. Kilburn

Texas A\&M International University

Department of Social Sciences, United States

jckilburn@tamiu.edu

Doi:10.5296/ jsr.v6i2.8038 URL: http://dx.doi.org/10.5296/ jsr.v6i2.8038

\begin{abstract}
This article seeks to identify short and long term effects of halfway house completion on parole success and subsequent recidivism from a sample of offenders released from a northeastern state's correctional facilities between 2004 and 2008. Using propensity score matching techniques, we compare parolees released to parole after successfully completing a residential treatment program to a matched group of parolees released directly into the community from a correctional facility. Analyses show that parolees who successfully complete a halfway house program are more likely to successfully complete parole but the effect on residential programming on long-term recidivism are negligible.
\end{abstract}

Keywords: Alternative Corrections, Community Corrections, Halfway Houses, Parole, Recidivism 


\section{Introduction}

Results of prior studies indicate that offenders released back into the community on parole are convicted of a new offense over $60 \%$ of the time (Ostermann 2010; 2011). Parole often results in technical violations that effect penalization as well (Petersilia and Turner 1993). In this article, we compare parole success and recidivism for a cohort of offenders who were released via traditional parole (also known as straight parole) to a matched group of incarcerated offenders released via a less commonly utilized form of reentry: reentry through a residential program, or halfway house.

Most often, parole is a situation where inmates are released into the community with obligations to report their actions (either frequently or periodically) to correctional agencies (Clear and Hardyman 1990). It has experienced escalated use in America since the 1970s. Bureau of Justice (BJS) statistics indicate that between 2000 and 2009, the number of offenders on parole increased from approximately 750,000 to 819,000 (Glaze and Bonczar 2009). Increased use of parole arose partially as a response to the idea that extended traditional incarceration was harmful to prisoners (Hall and Immageron 1998) and partially due to state fiscal crises associated with prison overcrowding (Austin and Krisberg 1982).

While the increased use of parole has probably provided some respite from prison overcrowding, unfavorable results regarding the outcome of parole as a form of community supervision are common in academic literature (Petersilia 2003; Simon 1993). Because parole is controversial as a form of release, it is useful to examine other community-based alternatives to reentry; such as transitional housing. However, because other forms of community reentry are more expensive (Kilburn and Costanza 2011) they are only used in marginalized context and for special cases (Freudenberg, Daniels, Crum, Perkins and Richie 2005). We focus two forms of community supervision: parole and residential treatment.

Corrections researchers have pointed to the challenges presented by growing numbers of people in need of community corrections programming (Glaze and Bonczar 2006; Gray, Conover and Hennessey 1978; Petersilia 1995; Jones 1991). The parole and probation system is becoming overloaded. Recent research indicates that community correctional officers are subject to secondary burnout and resilience issues stemming from large caseloads (Sachs 2010). Other research by Pitts and Taylor (2011) suggests that parole officers, especially male parole officers, may experience similar stress and subsequent burnout.

Some suggest a need for emphasis on community reintegration (Freudenberg 2001). Others have advocated minimizing the use of incarceration based on the idea that offenders are often victims of societal neglect (Hull and Knopp 1978). Others have suggested that more research on existing forms of community supervision is important to fiscal sustainability (Lowenkamp, et al. 2004).

Alternative post-correctional options, including substance abuse or mental health treatment programs are often discussed (Freudenberg et al. 2005; Gumurku 1968; Glaze and Bonczar 2006) among existing forms of community supervision are residential homes, which represent a community-based effort to facilitate offender reentry to society. While a small percentage of these facilities are private or "for-profit," most are funded with governmental 
money through stipends or tax subsidies (Byrne and Taxman 2005; Pratt and Winston 1999; Weisner and Room 1984). Ideally, residential facilities provide rehabilitation opportunities for residents.

Some positive effects of halfway houses on populations in transition have been documented (Gumrukcu 1968; Garrett 1985; Gouvis Roman and Travis 2004. Much research on transitional housing points out the perceived and real threats that transitional housing presents to communities (Piat 2000; Cowan 2003). While such transitional facilities simultaneously represent state-sponsored efforts toward easing taxpayer burdens and rehabilitation, communities often react poorly to the placement of such facilities (Orndoff 1978; Piat 2000a).

Halfway houses (like prisons) are unique surroundings that offer offenders a chance to network, learn either positive or negative values and make important social bonds. Social networks may develop positive resources like finding a job (Granovetter, 1973) or they may lead to the encouragement and learning of more criminal behavior (Sutherland, Cressey and Luckenbill, 1992). Unlike the conditions that define most parolees' circumstances, halfway house residents are more closely supervised. Ideally, residential facilities provide rehabilitation opportunities; however, it is known that intensive forms of supervision offer variable results.

This article explores the characteristics of those who successfully complete halfway houses. We assess type of reentry (halfway house participation or traditional parole) as a possible instrumental predictor of recidivism and technical violation. We follow the argument that: "The only scientifically credible method for assessing intervention effects is a research design that compares recidivism rates for offenders exposed to the intervention with those for a substantially similar control group with no exposure to it" (Lipsey and Cullen 2007, p.299).

Whether parole is a lower-risk option for both communities and inmates is an issue established here. The empirical study of halfway houses versus parole presents a very important public safety question. The costs of halfway houses cannot be measured simply in terms of taxpayer money, but also must be measured in terms of social justice. We also recognize that halfway houses, like parole agencies, are funded by taxpayers, therefore they must be also accountable for the quality and outcome of their services (Kilburn and Costanza 2011; Zippay and Lee 2008).

This article examines inmates who were released into the community on straight parole in 2004. They are statistically compared to those who experienced transitional residence through a halfway house program. We address the issue of whether participation in halfway house programs facilitates successful reentry or recidivism. The objectives of this research include, but are not limited to, answering the following questions:

1) Who successfully complete halfway house programs?

2) Who successfully completes parole?

3) Are halfway house participants rearrested and/or technically violated at different 
rates and time periods than inmates released through traditional parole?

4) What is the long-term success rate of halfway house completers when compared to similar ex-convicts who are released to parole?

\section{Relevant Literature}

There are three relevant types of literature examined. A first branch of literature involves discussion regarding former inmates who successfully complete traditional parole and their recidivism tendencies. The second type of literature focuses on individual characteristics of offenders who successfully complete halfway house programs and then parole (which we refer to in this paper as dual completion). The third type of literature involves assessment of quality and integrity in institutional programming, which often presents itself as a spurious factor in recidivism and is daunting to assess.

\section{Parole completion and recidivism:}

Research has shown mixed results as to characteristics of individuals who will successfully complete parole. Early literature emphasized that many of the same factors that led to desistance from criminal careers, would also be correlated with successful parole completion (Hart 1923). Factors correlated with parolee success include access to basic amenities such as clothes, a job and housing opportunities. In an early quantitative analysis of Massachusetts's parolees, Evans (1968) measured the impact of: higher wages, more skilled employment and stable employment on the successful completion of parole. He concluded that: "... labor market experience during parole is an important factor in parole completion." (p. 211). Recent work by Bellair and Kowalski (2010) among a cohort of Ohio parolees substantiates that indicators reflecting labor prospects in low-skill economic sectors help explain disaggregated race differences in serious criminal recidivism.

The Level of Service Inventory (Revised LSI-R) along with other risk assessment tools are commonly used by state agencies to assess the likelihood of parolees' success (Bonta and Matiuk 1990; Ward, Melser and Yates 2007). The LSI-R observes both time-tested factors (such as having a job on the outside and history of familial violence, etc.) and adds to them a measure of institutional risk (Bonta 1989; Girad and Wormith 2004). Institutional risk factors involve the assessment of whether offenders were guilty of institutional infractions as inmates. Such risk-factors are ideally assumed to correlate with the successful completion of parole and desistance from criminal careers.

Substance abuse and mental health are also taken into account in the LSI-R. Baillargeon, Williams, Mellow, Harzke, Hoge, Baillargeon and Greifinger (2009) examined the usefulness of the LSI-R as a tool in predicting parole revocation among 8,149 inmates who were released on parole from the Texas Department of Criminal Justice (TDCJ) in 2006. Logistic regression indicated that TDJC inmates with a dual diagnosis (those suffering from both major psychiatric disorder and a substance use disorder) were more likely to have their parole revoked than inmates with no psychiatric disorders.

Others studies have used successful completion of parole as a variable in predicting 
recidivism, which usually refers to criminal lapses after serving the obligation of a formal sanction. Ostermann (2010) discussed the many operationalizations of recidivism which include: any post intervention arrests for new crimes, felony arrests, charges filed by a prosecutor, reconvictions, reincarcerations for new crimes, returns to custody, absconding, and other infractions. Stiener, Markarios, Travis and Meade (2012) operationalized such behaviors as taking place among parolees during the first year of parole.

Using data taken from a New Jersey cohort released between 2006-2009; Ostermann (2010) examined: post-release arrests for a new crime; post-release convictions that resulted from new arrests and revocations of parole due to technical violations. Research indicated that supervision is effective, in that, those receiving supervision were less involved in crime than those not receiving supervision during release. However, regardless of the type of post-release supervision, Ostermann pointed out that a large number of parolees recidivate.

\section{Halfway House Completion as a predictor of successful parole and desistance}

Halfway house research has often focused on individual characteristics of the offender/resident and how these characteristics relate to both successful halfway house completion and recidivism/desistance after release. Findings by Walsh and Beck (1990) indicate that decreased alcohol use and attendance at religious services was associated with successful re-entry among halfway house participants. Hartmann and Friday (1994) did a follow-up study on halfway house discharges from a prison release cohort and found that racial minorities and unsuccessful program completers were more likely to recidivate. Hitchcock, Stainback and Roque (1995) found that those attending group sessions and individual therapy were most likely to be dual completers.

A 1996 study conducted by the Colorado Department of Public Safety (Colling-Chadwick 1996) examined a cohort of offenders released from transitional residences between 2000 and 2004. Upon measuring for completion among transitional housing clientele, researchers found that successful completers were: older, employed, more educated and had lower criminal history scores. In 2006, findings by another Colorado research team (Hetz-Burrell and English 2006) indicated that females were less likely to recidivate, as were those who participated in mental health programs and intensive supervision parole.

\section{Integrity in programming}

A third type of research involves a more general assessment of institutional characteristics associated with post-release services, and how these characteristics are related to outcomes. Some researchers have advanced the idea that integrity in correctional programming is as important as the achieved and ascribed characteristics of offenders. Gumrukcu (1968) suggested that the quality of staff-patient interaction contributed to success in mental health-specific halfway houses. The case of Correctional Services Corp. v. Malesko (2001), illustrates how transitional residences without substantial staff integrity can lead to problems. The case highlighted an incident of a halfway house resident with a heart condition being forced by a private correctional officer to climb five flights of stairs. The resident suffered a heart attack. 
Gendreau et al. (1999) stressed that the Correctional Program Assessment Inventory (CPAI) is an appropriate test of whether treatment programs work correctly. The CPAI provides an assessment of whether treatment programs show integrity in correctional interventions programming. For example, if a halfway house cannot provide a client network with qualified social service providers, then such a program may lack integrity. Since each halfway house differs in terms of its selection of staffing, programs and financing (Carpenter 1978; Kilburn and Costanza 2011) it is perhaps true that they should be assessed individually. The CPAI measures 4 factors with regard to institutional integrity: organizational integrity; program factors; change agent factors; and staff factors. Lowenkamp, Latessa, and Smith (2006) use the CPAI to facilitate in an evaluation of 38 Ohio halfway houses. The researchers found that failures in program implementation, such as cost effectiveness of the program, were significant predictors of offenders' readmission to prisons for new crimes.

Research by Bonta et al. (2008) showed that halfway houses with lower success rates had a lack of staff integrity and also were beleaguered by probation/parole officers who spent too much time on the enforcement aspect of supervision and not enough time on the service delivery role of supervision. This study suggests that probation/parole officers sometimes lack the necessary skills to influence behavioral change in their clients. Additionally, there are issues regarding staffing integrity. Integrity, in this sense, does not only refer to the personal motives/skills of correctional personnel, but the overall work conditions and occupational hazards of working in the correctional field. Research by Pitts and Taylor (2011) discussed the stressful experiences of probation/parole officers.

\section{Data and Methods}

Correctional and criminal history data were collected from a northeastern state on all inmates released to straight parole from correctional facilities between 2004 and 2008. These data included demographics, inmates' movements from and into correctional facilities and community supervision programs, risks and need assessment scores collected by the correctional facilities prior to inmates' release from prison, and criminal histories (i.e., arrests, convictions, and sentences prior to and four years following prison release). The key variables in our study are parole completion and recidivism after 12 months.

\section{Measures}

Data were collected from the corrections' management information system database and the state police criminal history databases. Data collected included: demographics (date of birth, sex, race/ethnicity, town of residence prior to incarceration), movement dates and types of movements into and out of correctional facilities (including halfway house releases and parole), and risks and needs scores. Risk and need scores were generated by correctional staff when inmates were first admitted to prison and every six months while incarcerated. Risk scores were calculated for inmates' history of violence, offense severity, length of prison sentence, correctional disciplinary history, security level, and overall risk. These scores were scaled from no risk (assigned a one) to high risk (assigned a four or five). Needs scores were created and used by the state to place inmates into appropriate correctional programming while institutionalized. Needs scores were coded from no need (a one) to 
high need (a five) for several categories including mental health, substance abuse, education and vocational.

Criminal histories were obtained for each inmate and consisted of arrest dates, charges, arraignment charges, verdicts and sentences. We used charges to create a measure for charge severity based on whether the charge was a felony, misdemeanor or violation. Parole completion was coded dichotomously with 1 assigned to parole completers (parolees successfully discharged from parole) and 0 for parolees who were remanded to prison for a new criminal offense or technical violation.

\section{Sample}

The original sample consisted of 1,946 parolees (1,522 were released from a correctional facility to parole and 424 were released from a correctional facility to a halfway house to parole). In order to test the effect of halfway house completion on parole success, it was imperative that this group be comprised of similar offenders. Propensity score matching techniques were used to create a parole group that closely resembled the halfway house parole group. Propensity scores were calculated using correctional risk and need scores, age at prison release, prior arrests, prior convictions, prior prison sentences, and offense severity.

Prior to calculating propensity scores, we eliminated parolees having a sex offender score because no sex offenders were in the halfway house parolee group. Also, we excluded parolees who had a high correctional risk score because they were not eligible for halfway house release prior to parole supervision. After performing these steps, there were only seven females in the parolee group so females were excluded in this study. Although there were 1,522 parolees released from a correctional facility, only 233 were included in the matching process.

Following the creation of propensity scores we stratified the sample by racelethnicity and type of town where parolees' lived prior to their incarceration (e.g., urban, suburban, rural). Halfway house parolees were then matched to parolees using nearest neighbor matching. We oversampled halfway house parolees to reduce variance across the propensity scores (Rassen, Shelat, Myers, Glynn, Rothman and Schneeweiss 2012; Smith and Todd 2005).

The matching procedures resulted in a study sample of 577 parolees (354 in the halfway house completion parole group and 223 in the comparative parole group). Table 1 presents the comparisons of the two study groups. There were no statistically significant differences between the groups for any of the defining variables 


\section{Macrothink}

Table 1. Sample Demographics and Results of Propensity Score Matching

\begin{tabular}{lcc}
\hline Variable & $\begin{array}{c}\text { Halfway House } \\
\text { Completers } \\
(\mathrm{n}=354)\end{array}$ & $\begin{array}{c}\text { Matched Sample* } \\
(\mathrm{n}=223)\end{array}$ \\
\hline Race/Ethnicity & $44 \%$ & $48 \%$ \\
$\quad$ Percent African-American & $23 \%$ & $22 \%$ \\
$\quad$ Percent Caucasian & $33 \%$ & $30 \%$ \\
$\quad$ Percent Hispanic & 31 & \\
Criminal History & 11 & 32 \\
Average Age at Prison Release & 3 & 11 \\
Average Prior Arrests & 8.0 & 3 \\
Average Prior Prison Sentences & & 8.0 \\
Offense Severity & 1.3 & \\
Correctional Needs/Risk Scores & 3.3 & 1.4 \\
Mental Health Needs Score & 2.5 & 3.4 \\
Substance Abuse Needs Score & 3.6 & 2.6 \\
Education Needs Score & 1.5 & 3.5 \\
Vocational Needs Score & 2.3 & 1.7 \\
Violence History Risk Score & 2.2 & 2.4 \\
Offense Severity Risk Score & 1.2 & 2.3 \\
Sentence Length Risk Score & 1.1 & 1.3 \\
Prison Discipline Risk Score & 1.0 & 1.1 \\
$\quad$ Security Risk Score & 1.0 \\
Overall Risk Score &
\end{tabular}

*There were no statistically significant differences at p. $<.05$

The most prevalent racial/ethnic group was African-American (44\% for the halfway house parole group and $48 \%$ for the facility group) with the average age between 31 and 32 years old. The average number of prior arrests for both study groups was 11 with the average number of prior prison sentences of 3 . Of the correctional-assessed needs and risk scores, the highest average needs were for vocational (3.6 for the halfway house group and 3.5 for the facility group), substance abuse (3.3 for the halfway house group and 3.4 for the facility group), and education ( 2.5 for the halfway house group and 2.6 for the facility group). The risk scores were fairly low for all of the risks (the averages being under 2.5).

\section{Findings}

\section{Univariate Analysis of Propensity-matched sample}

The first analyses compared each group's parole outcomes (successfully discharged from parole or rearrested/remanded while on parole) and recidivism one year after parole discharge. While it is possible for parolees to be remanded to prison and re-released on parole, we elected not to follow them after their initial remand. In comparing parole outcomes, the halfway house parole group had a statistically significant higher parole completion rate than 


\section{Macrothink}

the facility group (60\% of the halfway house parole group successfully completed compared to $48 \%$ of the facility parole group, $\left.\chi^{2}=6.93, \mathrm{df}=1, \mathrm{p} .<.05\right)$. These differences demonstrate that parolees who successfully complete a halfway house program were more likely to be successfully discharged from parole than parolees who were released from a correctional facility directly to parole.

We also followed parolees in both groups one year after they were successfully discharged from parole. The one-year follow-up period was used because it was possible that not all study participants had been discharged from parole for more than one year when the follow-up data were collected. One year after being successfully discharged from parole, halfway house parolees had a statistically significant lower rearrest rate (28\%) than facility parolees $(36 \%)\left(\chi^{2}=4.46, \mathrm{df}=1, \mathrm{p} .<.05\right)$. These two chi-square analyses found that parolees who successfully completed a halfway house program prior to parole release were more likely to be discharged from parole and less likely to be arrested following parole completion than parolees released from a correctional facility directly to parole.

\section{Multivariate Analysis of Parole Discharge and Recidivism After Parole Discharge}

The second analyses used logistic regression techniques to determine if halfway house completion was a significant and positive predictor of successful parole discharge and remaining crime-free after successful parole discharge. Table 2 presents the result of the first logistic regression analysis predicting successful parole discharge. There were four predictors of successful parole discharge: age at prison release (.35), risk score for offense severity (.55), risk score for sentence length (-.88), and halfway house completion (.53). In other words, older parolees who lived in a transitional residence and committed more serious offenses but were given shorter prison terms were most likely to successfully complete parole supervision. 
Table 2: Logistical Regression Analysis for Successful Parole Discharge

\begin{tabular}{lcccc}
\hline & B & Standard Error & Wald & Odds Ratio \\
\hline Age at Prison Release $^{* *}$ & 0.351 & 0.126 & 7.77 & 1.42 \\
Prior Arrests & -0.018 & 0.031 & 0.34 & 0.98 \\
Prior Convictions & -0.021 & 0.049 & 0.18 & 0.98 \\
Prior Prison Sentence & -0.050 & 0.041 & 1.51 & 0.95 \\
Offense Severity & 0.044 & 0.042 & 1.14 & 1.05 \\
Need: Mental Health & 0.014 & 0.154 & 0.01 & 1.01 \\
Need: Substance Abuse & -0.109 & 0.115 & 0.89 & 0.90 \\
Need: Education & -0.138 & 0.104 & 1.73 & 0.87 \\
Need: Vocational & 0.036 & 0.130 & 0.08 & 1.04 \\
Risk: Violence History & 0.002 & 0.111 & 0.00 & 1.00 \\
Risk: Severity of Offense ${ }^{* *}$ & 0.555 & 0.116 & 22.70 & 1.74 \\
Risk: Sentence Length & -0.887 & 0.195 & 20.68 & 0.41 \\
Half & 0.535 & 0.186 & 8.27 & 1.71 \\
Urban Residence & -0.139 & 0.194 & 0.51 & 0.87 \\
Drug Offender & 0.107 & 0.224 & 0.23 & 1.11 \\
Property Offender & -0.192 & 0.240 & 0.64 & 0.83 \\
Constant & 0.451 & 0.910 & 0.25 & 1.57 \\
\hline
\end{tabular}

Nagelkerke $R^{2}=14$, Cox and Snell $R^{2}=.11$

**Slope is statistically significant at $\mathrm{p}<05$.

Of key interest is the halfway house completion indicator. Parolees who successfully completed a halfway house program were more likely to successfully be discharged from parole. The odds ratio of 1.71 indicates that halfway house completers were almost twice as likely to complete parole as parolees straight out of correctional facilities.

For those parolees who successfully completed parole (212 halfway house parolees and 107 facility parolees), we examined arrest rates up to one year following parole discharge and conducted a similar logistic regression analysis (Table 3). 
Table 3: Logistic Regression for New Arrest One Year Following Successful Parole Discharge

\begin{tabular}{lcccc}
\hline & B & Standard Error & Wald & Odds Ratio \\
\hline Age at Prison Release $^{* *}$ & -0.436 & 0.215 & 4.13 & 0.65 \\
Prior Arrests & 0.082 & 0.047 & 3.02 & 1.09 \\
Prior Convictions & -0.056 & 0.073 & 0.57 & 0.95 \\
Prior Prison Sentence & 0.001 & 0.067 & 0.00 & 1.00 \\
Offense Severity & -0.111 & 0.060 & 3.37 & 0.90 \\
Need: Mental Health & -0.026 & 0.271 & 0.01 & 0.97 \\
Need: Substance Abuse & -0.027 & 0.174 & 0.02 & 0.97 \\
Need: Education & -0.099 & 0.164 & 0.37 & 0.91 \\
Need: Vocational & 0.414 & 0.198 & 4.39 & 1.51 \\
Risk: Violence History & 0.264 & 0.156 & 2.84 & 1.30 \\
Risk: Severity of Offense & 0.029 & 0.163 & 0.03 & 1.03 \\
Risk: Sentence Length ${ }^{* *}$ & -0.720 & 0.372 & 3.74 & 0.49 \\
Halfway House Completion ${ }^{*}$ & -0.487 & 0.287 & 2.87 & 0.62 \\
Urban Residence & -0.037 & 0.284 & 0.02 & 0.96 \\
Drug Offender & -0.529 & 0.335 & 2.50 & 0.59 \\
Property Offender & 0.141 & 0.349 & 0.16 & 1.15 \\
Constant & 1.207 & 1.494 & 0.65 & 3.34 \\
\hline
\end{tabular}

Nagelkerke $\mathrm{R}^{2}=19$, Cox and Snell $\mathrm{R}^{2}=.14$

**Slope is statistically significant at $\mathrm{p} .<05$.

There were three statistically significant predictors of rear rest at the .05 level: age at prison release (-.43), vocational need (.41) and sentence length (-.72). As is the case with successful parole completion, there are similar variables that result in a lower likelihood of rear rest. Offenders who most likely to be rearrested one year following parole discharge were younger, had shorter prison sentences, and had higher vocational needs.

There were two statistically significant predictors of recidivism at the .10 level, halfway house completion (-.48) and drug offender (-.52). Those inmates who completed residential transition were almost half as likely (0.42) to recidivate after release. Those parolees who had committed drug violations were less likely to be rearrested (0.59). These finding confirms much of the classic literature about social bonding and desistance (see: Hirschi 1969, Shover 1985) as well as an confirming an early finding on parole completion by Evans (1967). Although halfway house completion may be vital to some inmates developing social networks and life skills, regardless of halfway house completion, there are still many variables that are more powerful predictors of recidivism.

\section{Discussion}

In this analysis, we show that successful halfway house completion produces short-term and long-term positive effects even in the presence of several other variables that have significant effects on parole completion and recidivism. Moreover, when factored in with a matched set of traditional parolees, halfway house completers were almost two times as likely to 
successfully complete parole. In addition, successful completers of a halfway house program were almost half as likely to recidivate as a matched sample of clients who were either released directly into the community or selected for halfway house programming and failed during transition.

The findings of this study do not directly confirm, but imply that certain types of offenders might benefit more from successful residential completion than others. Specifically, we may look at the parolees in the propensity-matched sample who succeed (or fail) regardless of halfway house programming. It makes sense to assume that people who are already predisposed to recidivate will probably not benefit a great deal from what halfway house programming has to offer. Given the cost of rehabilitation, state correctional systems may find a best practices approach to consider allocation of resources for transitional residences to those who are already statistically low probabilities for recidivism.

First, older parolees are significantly more likely to be successfully discharged from parole and less likely to experience recidivism issues. It is possible that older clients may experience more benefits from halfway house programming, given their lower probability for recidivism. Second, parolees with longer sentence lengths and parolees who were initially locked up on drug charges are significantly more likely to experience successful discharge from parole and lower recidivism rates.

For groups of offenders who had long stays in prison, halfway house programming and supervision may be helpful while gradually reintegrating them back into their communities. Reentry from several years in prison could be facilitated by well-programmed transitional residences. For drug offenders, transitional supervision might provide networking opportunities for additional medical care and/or relapse prevention.

A final finding is that parolees with a high need for vocational skills are more likely to recidivate. In this sense, the halfway house could proved additional opportunity for parolees who already have marketable skills. Halfway house programming could focus on preventing recidivism through enhancing contacts with labor markets.

Of course, an alternate response might be to state-sponsored halfway house programming to serve those parolees who are most likely to recidivate. Such a strategy would involve targeting younger, non-vocationally skilled, non-drug offenders who have had the shortest terms in prison for halfway house placement. However, given the tension between halfway houses in many of the communities they are placed in, this would probably create a great deal of uneasiness or political controversy.

\section{Conclusions}

Parolees who effectively complete halfway house programming significantly vary from people released on straight parole in both successful parole completion and recidivism within one year of discharge. However, these results are not surprising considering that many states already segregate high-risk parolees from low-risk parolees when considering halfway house placement options. In the northeastern state that this study was conducted in, for example, sex offenders and high-risk violent criminals are not eligible for halfway house 
placement. This is partially due to liability concerns about criminal behavior and partially due to sensitivity to community concerns about safety and well being. Halfway houses may take away a sense of community in neighborhoods and ultimately culminate in "not in my backyard" (NIMBY) grassroots movements (Costanza, Kilburn and Vendetti-Koski 2013).

Public support for social programs, such as halfway houses, has been weak since the 1970s. At some level, the issue of halfway houses becomes one of economic sustainability. As prisons become more crowded, further research should examine the economic benefits of halfway house programs versus the potential losses. "How much can be saved by the state from the implementation of halfway house programs?" remains a paramount question to be addressed. Residential programming is often more expensive than straight parole, especially when such programming involves substance abuse treatment (Byrne and Taxman 2005; Griffith, Hiller, Knight and Simpson, 1999).

A next step in research may be to obtain and analyze data from another state that allows higher risk parolees to participate in halfway house programming. Findings here indicate that successful completers of transitional programming are less likely to recidivate than others, however the low risk that halfway house residents already present may be a spurious factor. As noted, these findings seem to support some of the classic theories on social control and recidivism. Age, as an important factor in measuring recidivism was first proclaimed by Travis Hirschi (1969). Shover (1985) advanced the idea that ties to a job and amount of previous time served would facilitate desistance from criminal activity. We feel that similar findings could be replicated in a state such as Texas that is less discriminatory about who is selected for halfway house programming.

Another impetus for future study should be a concern with variables that predict integrity of halfway house programming as it relates to successful parole completion and recidivism. Our data only included limited demographics and institutional data about the population being researched, and no data on the transitional residences where these parolees were placed. Our data do not tell us whether that halfway houses under observation were functioning with integrity. Program quality may combine with several individual factors (such as age and severity of offense) to affect the actual benefits received from transitional residential programs by clientele.

\section{References}

Andreas, P. (2000). Border games: Policing the U.S.-Mexico divide. Ithaca, NY: Cornell University Press.

Baillargeon, J., Williams, B. A., Mellow, J., Harzke, A.J., Hoge, S.K., Baillargeon, G. \&

Greifinger, R.B. (2009). Parole Revocation Among Prison Inmates With Psychiatric and Substance Use Disorders. Psychiatric Services. 60, 11.

Bellair, P.E. \& Kowalski, B.R. (2011). Low-Skill Employment Opportunity and African 
American-White Difference in Recidivism Journal of Research in Crime and

Delinquency. $\quad 48,176-208$.

Bonta, J., Rugge, T., Scott, T., Bourgon, G., and Yessine, A.K. (2008). Exploring the Black Box of Community Supervision. Journal of Offender Rehabilitation, 47, 248-270.

Carpenter, M. D. (1978). “A Follow-up Study of Berkeley House: A Psychiatric

Halfway House” International Journal of Social Psychiatry, 23, 120-131.

Colling-Chadwick, S. (1996). ”Comparison of Intensive Supervision Probation and

Community Corrections Clientele." [technical report] prepared for the Drug Control and Systems Improvement Program, Colorado Division of Criminal Justice, Denver, Colorado.

Cowan, S. (2003). NIMBY syndrome and public consultation policy: The implications of a discourse analysis of local response to the establishment of a community mental health facility. Health and Social Care in the Community, 11, 379-386.

Costanza, S. E. \& Kilburn, J.C. (2005). Symbolic Security, Moral Panic and Public Sentiment: Toward a Sociology of Counterterrorism. Journal of Social and Ecological Boundaries, 1, 106-124.

Costanza, S.E.; Kilburn Jr.. John C. and Vendetti-Koski, Susan (2013). Are minority areas disproportionately targeted for halfway house placement?" , Journal of Ethnicity in Criminal Justice 11: 256-276.

Clear, T. and Hardyman, P. (1990). The new intensive supervision movement. Crime and Delinquency 36, 1, 42-60.

Daly K. \& Immarigeon, R. (1998). "The past, present, and future of restorative justice: some critical reflections." The Contemporary Justice Review 1, 21-45.

Evans R. (1968). “Labor Market and Parole Success.” The Journal of Human

Resources, 3, 201-212.

Freudenberg N. (2001). "Jails, prisons, and the health of urban populations: A

review of the impact of the correctional system on community health" Journal of Urban Health. 78, 214-235.

Freudenberg, N., Daniels, J., Crum, M., Perkins, T. \& Richie, B.

(2005). "Coming Home From Jail: The Social and Health Consequences of

Community Reentry for Women, Male Adolescents, and Their Families and Communities" American Journal of Public Health 95, 1725-1736.

Gendreau, P. \& Andrews, D. A. (1996). Correctional Program Assessment Inventory (CPAI) 6th Edition. Saint John, New Brunswick. 


\section{I Macrothink}

Gendreau, P., Goggin, C. \& Smith, P. (1999). The Forgotten Issue in Effective Correctional Treatment: Program Implementation. International Journal of Offender Therapy and Comparative Criminology, 43, 180-187.

Glaze L.E. and Bonczar T.P. (2006). Probation and Parole in the United

States, 2005. Washington, DC: Bureau Justice Stat., U.S. Dept. Justice

Granovetter, M.S. (1973). The Strength of Weak Ties. American Journal of Sociology,

$78,1360-80$.

Griffith, J.D., Hiller, M.L., Knight, K. \& Simpson, D.D. (1999). A Cost-Effectiveness

Analysis of In-Prison Therapeutic Community Treatment and Risk Classification.

The Prison Journal. 79, 352-68.

Gumrukcu, P. (1968). The Efficacy of a Psychiatric Halfway House: A. Three-year Study of a Therapeutic Residence. Sociological Quarterly, 9, 374-386.

Hart, H. (1923). "Predicting Parole Success" Journal of Criminal Law and Criminology 14: 405-413

Hart, T., Callie M., Rennison, C., \& Gibson, C. (2005). Revisiting respondent "fatigue bias" in the national crime victimization survey. Journal of Quantitative Criminology, 21, 345-363.

Hartmann, D. J. and Friday, P.C. (1994). Residential Probation: A Seven-Year Follow up Study of Halfway House Discharges. Journal of Criminal Justice, 22, 503-515.

Hetz-Burrell, N.H. \& English, K. (2006). "Community Corrections in Colorado: A Study of Program Outcomes and Recidivism, FY00-FY04" [technical report] prepared for Office of Research and Statistics, Division of Criminal Justice, Colorado Department of Public Safety.

Hirschi, T. (1969). A control theory of delinquency. Criminology theory: Selected classic readings, 289-305.

Hitchcock, H.C., Stainback, R.D., \& Roque, G.M. (1995). Effects of Halfway House Placement on Retention of Patients in Substance Abuse Aftercare. American Journal of Drug \& Alcohol Abuse, 21, 379-390.

Hunter, S. and Leyden, K.M. (1995). Beyond NIMBY: Explaining opposition to hazardous waste facilities. Policy Studies Journal, 23, 601-620.

Johnson, M.P. (2006). Decision Models for the Location of Community Corrections Centers. Environmental Planning \& Design, 33, 393-412.

Kilburn, J.C. and Costanza, S.E. (2011). Salvation city: Halfway House Stories. Amherst, NY: Teneo Press.

Kraft, M.E. and Clary, B. B. (1991). Citizen participation and the NIMBY syndrome: public 
response to radioactive-waste disposal. The Western Political Quarterly, 44, 299-328.

Krause, J. D. (1991). “Community Opposition to Correctional Facility Siting: Beyond the “NIMBY” Explanation.” Humboldt Journal of Social Relations. 17, 239-262.

Lipsey, M.W. \& Cullen. F.T. (2007). “The Effectiveness of Correctional

Rehabilitation: A Review of Systematic Reviews." Annual Review of Law and Social Science. 3, 297-320.

Lowenkamp, C. T., Latessa, E. J. and Smith, P. (2006). Does correctional program quality really matter? The impact of adhering to the principles of effective intervention. Criminology \& Public Policy, 5, 571-84.

Petersilia, J. (2003). When prisoners come home: Parole and prisoner reentry. New York:

Oxford University Press.

Petersilia, J. and Turner, S. (1993). Intensive Probation and Parole. Crime and Justice 17, 281-335.

Piat, M. (2000a). "Becoming the victim: A study on community reactions towards group homes." Psychiatric Rehabilitation Journal. 24, 108-116.

Piat, M. (2000b). “The NIMBY phenomenon: Community residents' concerns about housing for deinstitutionalized people." Health \& Social Work. 25, 127-138.

Piquero, N.L. (2003). A recidivism analysis of Maryland's community probation program. Journal of Criminal Justice, 31, 295-307.

Quinn, J. F. (2003). Corrections; A Concise Introduction. Prospect Heights, IL: Waveland Press.

Rassen, J.A., Shelat, A.A., Glynn, R.J., Rothman, K.J., and Schneeweiss, S. (2012). One-to-many propensity score matching in cohort studies. Pharmacoepidemiology and Drug Safety, 21, 69-80.

Schively, C. (2007). "Future Research Understanding the NIMBY and LULU Phenomena: Reassessing Our Knowledge Base and Informing Future Research" Journal of Planning Literature 21, 255-266.

Shover, N. (1985). Aging criminals. Beverly Hills: Sage Publications.

Silverman, I. (2001). Corrections: A Comprehensive View. Belmont, CA.: Wadsworth Publishing.

Simon, J. (1993). Poor Discipline: Parole and the Social Control of the Underclass, 1890-1990. Chicago: University of Chicago Press. 


\section{Macrothink}

Journal of Sociological Research

ISSN 1948-5468 2015, Vol. 6, No. 2

Smith, J. and Todd, P. (2005). Does matching overcome LaLonde's critique of nonexperimental estimators? Journal of Econometrics, 125, 305-353.

Sutherland, E. H., Cressey, D.R. \& Luckinbill, D.F. (1992). Principles of Criminology. Dix Hills, N.J.: General Hall.

Travis, J. and Visher, C. A. (2005). Prisoner reentry and crime in America. New York: Cambridge University Press.

Travis, J. (2005). But they all come back: Facing the challenges of prisoner reentry. Boston, MA: Urban Institute Press.

Walsh, C. L. \& Beck, S.H. (1990). Recidivism Among Halfway House Residents. Journal of Criminal Justice 15, 137-49.

Zippay, A., \& Lee, S. (2008). Neighbors' perceptions of community-based psychiatric housing. Social Service Review, 82(3), 395-417. 